\title{
Psychoanalysis: a philosophical critique ${ }^{1}$
}

Adolf Grünbaum, who is a professor of philosophy and a research professor of psychiatry, has devoted a great deal of thought to the question of whether psychoanalysis can be, or should be, regarded as a natural science, as Freud had proclaimed throughout his long career. In pursuit of this quest he undertook a very thorough exegesis of the Standard Edition of the Complete Psychological Works of Sigmund Freud $(S E)$ and published his philosophical exploration of psychoanalysis in 1984 in a volume entitled The Foundations of Psychoanalysis. A Philosophical Critique $(F)$. Since this caused a very understandable stir, the editor of Behavioral and Brain Sciences $(B B S)$ invited Grünbaum to write a précis of his book and to reply to the peer review of 41 experts (Grünbaum, 1986).

Grünbaum saw it as his first task to demonstrate that opponents of the view that psychoanalysis is a natural science are wrong. He began with philosophers whom he called 'hermeneuticists' or 'hermeneuticians', in particular Jürgen Habermas in Germany and Paul Ricoeur in France. In Grünbaum's words, hermeneutics had been grafted 'from its original philological context (biblical exegesis) on to psychology' $(F$, p. 91$)$. But this is certainly only part of the story. The hermeneuticists in question are really adherents of 'hermeneutic phenomenology' as originally elaborated by Martin Heidegger in his Sein und Zeit (1977, orig. 1927). There he deviated from his teacher, Edmund Husserl, in his concept of phenomenology by maintaining that 'the phenomenology of human being (Dasein) is hermeneutic in the original sense of the word according to which its task is interpretation (Auslegung)', namely uncovering the Being (Sein) that is hidden in human being (Da-Sein) (p. 37, emphasis in original as in all subsequent quotations in this editorial). Habermas and Ricoeur adapted hermeneutic phenomenology in a way that allowed them to 'put forward the so-called hermeneutic reconstruction of the Freudian corpus in order to supplant Freud's own view of the psychoanalytic enterprise as a natural science' (BBS, p. 217). Grünbaum argued at great length that they are mistaken, largely because they maintain that causality works only in the physical world but not in the mental realm. He asserted that 'the generic disavowal of causal attributions advocated by the radical hermeneuticians is a nihilistic, if not frivolous, trivialization of Freud's entire clinical theory' $(F$, p. 58$)$. 'If a repression $\mathrm{R}$ is, indeed, the psychic pathogen of a neurosis $\mathrm{N}$, then the presence of $\mathrm{R}$ is causally relevant to the incidence of $\mathrm{N}$ in the class of those who harbor $\mathrm{R}$, precisely because it makes a difference to becoming afflicted by $\mathrm{N}$. And $\mathrm{R}$ is held to affect the incidence of $\mathrm{N}$ in the same sense as a bona fide carcinogen affects the somatic incidence of cancer' $(F, \mathrm{p} .72)$.

Grünbaum demolished the views of hermeneutic phenomenology to his own satisfaction. But he did not mention Karl Jaspers in this context, who (though only a descriptive, and not a hermeneutic, phenomenologist) had certainly a much wider grasp of psychopathology than other philosophers, Grünbaum included (who admits his lack of clinical experience). Jaspers (1963) is quite outspoken in his phenomenological criticism of Freud: ' 1 . Freud is actually concerned with the psychology of meaningful connections and not with causal explanations as he himself believed. 2. Freud teaches us in a most convincing way to recognize many particular meaningful connections. 3 . The falseness of the Freudian claim lies in the mistaking of meaningful connections for causal connections. 4 . In a great number of cases Freud is concerned neither with understanding the meaning of unnoticed connections nor with the bringing of them into consciousness but with a "hypothetical understanding of extra-conscious connections"' (1963, p. 539, orig. 1946).

Thus, the views of phenomenologists, on the one hand, and of Freud and Grünbaum, on the other, are utterly at variance. Grünbaum may, of course, reply that he did not engage in battle with

1 Address for correspondence: Dr F. Kräupl Taylor, 22, Redington Road, London NW3 7RG. 
phenomenologists in general, but only with hermeneutic psychoanalysts. In that case, however, it seems that he has used a battering ram against an open door. Hermeneutic psychoanalysts are not Freudians and do not consider themselves to be natural scientists or to deal with objectively observable facts other than those that occur in the form of verbal and non-verbal communications in the psychoanalytical situation, and these are noticed only as bearers of meaning.

Grünbaum then tackled a more definite, and also more formidable, opponent in the person of Sir Karl Popper. He allowed himself here a few vendetta remarks, such as accusing Popper of 'exegetical legerdemain' and 'sheer travesty' in presenting Freud's views because, in a footnote, 'Popper simply truncated Freud's crucial sentence in a highly misleading way without any indication of this omission' $(F$, p. 284). It is amusing that, in the peer review, Grünbaum is himself convicted of the same offence by Notturno and $\mathrm{McHugh}(B B S, \mathrm{p} .251)$. However, Grünbaum had some serious objections to Popper's criticism of psychoanalytic theory. He pointed out that Popper makes two relevant claims which are logically independent, namely '(1) logically, psychoanalytic theory is irrefutable by any human behavior, and (2) in the face of seemingly adverse evidence, Freud and his followers always dodged refutation by resorting to [what Popper called] immunizing manouvers' (BBS, p. 268). The first of these claims is logically of greater significance and Grünbaum argued that it is not possible to prove 'the falsity of the following existential statement: the infinite Tarskian consequence class of the psychoanalytic theoretical corpus does contain at least one member that qualifies as an empirical statement about human behavior' $(F$, p. 113).

One would like to know Popper's reply to this challenge, but unfortunately he does not know about it as he did not read Grünbaum's book. He was merely contacted by a journalist who had interviewed Grünbaum and on whose advice Popper was asked to comment on the following Freudian statement which Grünbaum regarded as testable: 'Repression of traumatic experiences is essential for neurosis to develop' ( $B B S$, p. 266). Popper promptly denied the testability of this statement. Among his reasons were these: 'Freud has often asserted that everybody is neurotic (to a greater or lesser degree). So how can [this statement and a related one] whose testability depends on the prediction of nonneurosis be clearly testable? ... Scientific testability is a question of overt behavior. It cannot be achieved by speaking of alleged or hidden states such as "repression" or "trauma" or "neurosis", states whose hypothetical presence or absence cannot be tested (and of which it even remains questionable whether they are ever absent)' ( $B B S$, p. 255).

Grünbaum did not contest Popper's reply. Instead he apologized, explaining that for 'journalistic simplicity' he had not asked a cardinal question, but had allowed a 'vaguer version' of the Breuer-Freud hypothesis about the pathogenesis of hysteria to be submitted to Popper. A less vague version was Freud's hypothesis that paranoia is due to repressed homosexuality. Grünbaum may have regarded it as less vague because it seemed more easily testable. It would, for example, be falsified by any paranoid patient who engaged in overt homosexual activities. It so happened that Popper had an opportunity elsewhere to consider this paranoid hypothesis. He pointed out that it 'is not part of the basic theory I was criticizing. Besides Freud could say of any apparently paranoid homosexual that he is not really paranoid, or not fully active' (BBS, p. 267).

Grünbaum took Popper to task for saying that the paranoia hypothesis was not part of the 'basic' Freudian theory and he added the highly debatable remark that it 'is part of Freud's theory of psychopathology, which is the most "basic" part of the theory of repression' (BBS, p. 267). He then turned to Popper's suggestion that, in order to save his hypothesis, Freud would have resorted to the immunizing procedures indicated. He admitted reluctantly that the diagnosis of paranoia was always open to doubt like any other psychiatric diagnosis, but he firmly denied that Freud could ever have entertained the possibility of any paranoid patient being capable of homosexual activity, whether fully or partly. Therefore any overt homosexual who was definitely paranoid would sound the death knell of Freud's paranoia hypothesis. Yet one cannot agree with Grünbaum that this would make a big dent in the whole corpus of Freudian hypotheses.

There is no doubt that Freud used immunizing procedures when any of his hypotheses ran into trouble. In this respect he was indeed in good company, as many natural scientists have acted in the same theory-saving manner. Nor is this always scientifically reprehensible, as Popper has pointed out, provided the immunizing manoeuvre is empirically testable (cf. Popper, 1976, p. 42). 
Grünbaum argued that Freud did not arbitrarily modify his hypotheses, but only when he found them to be wrong. They were thus falsifiable and therefore, in principle, scientific by Popper's criterion, provided no recourse was had to untestable immunizations. It could thus be said that, in principle, there are no insurmountable logical or empirical reasons for withholding the accolade of scientific merit from psychoanalysis.

Having established this point, Grünbaum investigated whether 'Freud's actual criteria for theory validation were essentially those of hypothetico-deductive inductivism since Freud regarded adherence to these as the hallmark of the scientific status he claimed for his theory' (BBS, p. 220). He found that Freud indeed intended to live up to these criteria. From Freud's 'Analytic Therapy' lecture in 1917, Grünbaum teased out two basic premises on which Freud relied. They consisted of the following conditional statements:

1. If a patient is permanently cured of his neurosis, then he must have been given correct insight into the aetiology of his illness.

2. If a patient has obtained correct insight, then he must have received psychoanalytic treatment.

The conjunction of these two conditional statements, Grünbaum called Freud's 'Necessary Condition Thesis', or ' $N C T$ ', for short. It has two corollaries, namely (a) that only psychoanalysis can cure a patient and (b) that there are no spontaneous cures of neurosis. If one adds to the NCT the existential statement: 'There are patients who have been permanently cured by psychoanalysis', then two conclusions follow:

'Conclusion 1. The psychoanalytic interpretations of the hidden causes of P's [the patient's] behavior given to him by his analyst are indeed correct, and thus - as Freud put it - these interpretations "tally with what is real" in $\mathrm{P}$ ' $(F$, p. 140).

Conclusion 2 is merely a repetition of the above corollary (a). Grünbaum referred to these conclusions as the 'Tally Argument'.

On the basis of this Tally Argument, Grünbaum declared Freud to be 'a sophisticated scientific methodologist' $(F$, p. 128). Yet 'before a decade had elapsed, however, even Freud's own evidence conflicted with the claim that the cure of a neurosis depends on the patient's correct insight into its causes [this means the collapse of the first premise of NCT]. Thus, by 1926, he conceded that his type of treatment was not indispensable (collapse of corollary (a), the existential statement and Conclusion 2) and merely expedited recoveries that were in the offing anyway ( $S E, 1926,20: 154)$. Then in 1937 Freud went on to report that a satisfactory psychoanalysis will not even prevent the recurrence of the problem for which the patient was treated, let alone immunize him against the outbreak of a different one (SE, 1937, 23:216-53). Thus, far from holding out hope for cures, Freud essentially confined the prospects of psychoanalysis to palliation' ( $B B S$, p. 222). The Tally Argument was therefore dead. Yet Freud continued as though nothing had happened, causing Grünbaum to lament that Freud's reasoning was 'grievously and fundamentally flawed'.

Without the Tally Argument as a basis, the psychoanalytic concepts of repression and free association, as well as the interpretation of dreams and parapraxes, were hanging in the air. Grünbaum was driven to these conclusions: 'I claim that it [the repression aetiology of neuroses] should now be regarded as generically devoid of clinical evidential support.... I maintain that the demise of the therapeutic justification for the repression etiology fundamentally impugns the investigative cogency of lifting repressions via "free" associations' $(F, p .185 \mathrm{f})$. He underlined that the associations of an analysand are not really free because they are contaminated by the "myriad ways in which he [the analyst] can unconsciously but persuasively mould the analysand's convictions and engender a compliant corroboration' $(F, \mathrm{p} .31)$. Even if 'free' associations were not contaminated by the analyst's interpretations and suggestive influences, they would still not contribute to a proof that the repressed conflicts they are supposed to uncover are the causes of neuroses, dreams or parapraxes. 'Not even the tortures of the thumbscrew or of the rack should persuade a rational human-being that free associations can certify pathogens or other causes' $(F$, p. 186). 'I view his [Freud's] theory of parapraxes and of dreams as misextrapolations of the generic repression theory' ( $F$, p. 194) - a theory which in itself is not tenable.

Grünbaum thus came to the conclusion that 'there is woefully insufficient ground to vindicate the intraclinical testability of the cardinal tenets of psychoanalysis' $(F$, p. 128). Because of the 
'epistemic defects inherent in the psychoanalytic method, it would seem that the validation of Freud's cardinal hypotheses has come, if at all, mainly from well-designed extraclinical studies, either epidemiologic or even experimental [references omitted]. But that appraisal is largely a task for the future' $(F$, p. 278).

The peer review and Grünbaum's answers to it did not yield anything substantially new. The only surprising finding was that even Grünbaum, when in hot pursuit of a debating point, could stray from the narrow path of sound reasoning and plunge into an obvious blunder. This happened in his long reply to Cioffi whom he accused of failing to adduce textual documentation. He singled out this particular question by Cioffi: 'Isn't it strange that Freud should think his most irrefragable proof came from just those conditions, for example, dementia praecox, which are resistant to psychoanalytic treatment?' $(B B S$, p. 231). Grünbaum replied: 'On the contrary, the 1980 computerresearched Concordance to the Standard Edition (ed. Guttman, Jones \& Parrish) shows that the only context in which Freud ever spoke of "irrefragable proof", in any of the 24 volumes, turns out to be a therapeutic one that is grist for $m y$ mill' ( $B B S$, p. 272). But Freud never wrote of 'irrefragable proof', as this expression does not occur in the German language. Grünbaum scored a debating point by courtesy of Freud's translator who happened to use this expression in a context favourable to Grünbaum's argument. 'For the Snark was a Boojum, you see', as the logician, Lewis Carroll, had once warned unwary English-speakers.

At the end of his book, Grünbaum's assessment of Freud seems to have undergone a distinct change. Freud was no longer 'a sophisticated scientific methodologist' $(F$, p. 128), but a man with a 'brilliant theoretical imagination [who] was actually quite serendipitous for psychopathology or the understanding of some subclass of slips' $(F$, p. 278). This assessment brings to one's mind two quondam illustrious Viennese physicians who had been hailed as trail-blazing scientists for many years and were later found to have had serendipitous ideas; they were Mesmer, the healer by rapport and magnetism, and Gall, the phrenological diagnostician of personality. Mesmer's thoughts live on in altered form in transference and hypnotism, and those of Gall in the cerebral localization of mental functions.

Surveying the havoc wrought by Grünbaum's heavy guns of criticism on the claim that psychoanalysis is a natural science, one may begin to wonder whether the claim is now dead and buried. This would, of course, fall in with Popper's diagnosis - and that would never do. 'Psychoanalysis', Grünbaum avers, 'may... be said to be scientifically alive, [though] it is currently hardly well, at least insofar as its clinical foundations are concerned. Nor is there a favorable verdict from such experimental findings as we had occasion to canvass...' ( $F$, p. 278). 'At least with respect to the available clinical evidence, psychoanalysis is a bad science' (BBS, p. 268), but not a dead one.

F. KRÄUPL TAYLOR

\section{REFERENCES}

Freud, S. $(1926,1937)$. Standard Edition of the Complete Psychological Works of Sigmund Freud (1953-1974). (Transl. and ed. James Strachey with Anna Freud, Alix Strachey and Alan Tyson). The Hogarth Press and Institute of Psychoanalysis: London.

Grünbaum, A. (1984). The Foundations of Psychoanalysis. A Philosophical Critique. University of California Press: Berkeley.

Grünbaum, A. (1986). Précis of ' The Foundations of Psychoanalysis: a Philosophical Critique' The Behavioral and Brain Sciences 9, 217-228.

Heidegger, M. (1977, orig. 1927). Sein und Zeit. 14th edition. Max Niemeyer: Tübingen.

Jaspers, K. (1963, orig. 1946). General Psychopathology. 7th edition. Transl by J. Hoenig and M. W. Hamilton. Manchester University Press: Manchester.

Popper, K. (1976). Unended Quest. An Intellectual Autobiography. Fontana/Collins: Glasgow. 